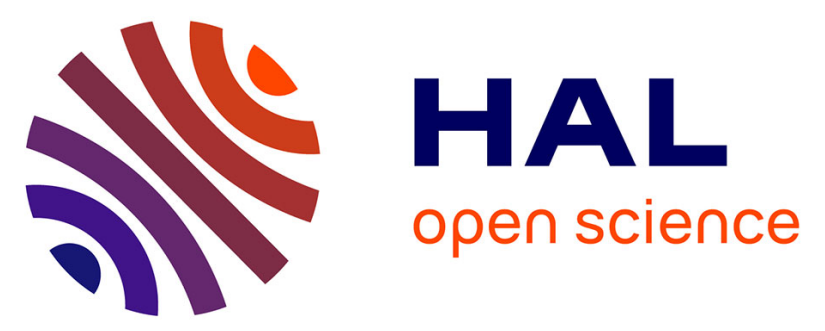

\title{
Effect of titanium dioxide film thickness on photocatalytic and bactericidal activities against Listeria monocytogenes
}

Marion Barthomeuf, Xavier Castel, Laurent Le Gendre, Justine Louis, Martine Denis, Christine Pissavin

\section{To cite this version:}

Marion Barthomeuf, Xavier Castel, Laurent Le Gendre, Justine Louis, Martine Denis, et al.. Effect of titanium dioxide film thickness on photocatalytic and bactericidal activities against Listeria monocytogenes. Photochemistry and Photobiology, 2019, 95 (4), pp.1035-1044. 10.1111/php.13078 . hal-01966652

\section{HAL Id: hal-01966652 \\ https://hal.science/hal-01966652}

Submitted on 14 Jan 2019

HAL is a multi-disciplinary open access archive for the deposit and dissemination of scientific research documents, whether they are published or not. The documents may come from teaching and research institutions in France or abroad, or from public or private research centers.
L'archive ouverte pluridisciplinaire HAL, est destinée au dépôt et à la diffusion de documents scientifiques de niveau recherche, publiés ou non, émanant des établissements d'enseignement et de recherche français ou étrangers, des laboratoires publics ou privés. 


\title{
Effect of titanium dioxide film thickness on photocatalytic and
}

\section{bactericidal activities against Listeria monocytogenes}

\author{
Marion Barthomeuf ${ }^{1}$, Xavier Castel ${ }^{2}$, Laurent Le Gendre ${ }^{2}$, Justine Louis ${ }^{1}$, Martine \\ Denis $^{3}$, Christine Pissavin* $*^{1}$ \\ 1. Univ Rennes, F-22000 Saint-Brieuc, France \\ 2. Univ Rennes, CNRS, IETR - UMR 6164, F-22000 Saint-Brieuc, France \\ ${ }^{3}$. Anses - Laboratoire de Ploufragan-Plouzané / Unité Hygiène et Qualité des Produits Avicoles et \\ Porcins, F-22440 Ploufragan, France \\ *Corresponding author e-mail: christine.pissavin@univ-rennes1.fr (Christine Pissavin)
}

\begin{abstract}
Structural, microstructural and bactericidal surface properties of $\mathrm{TiO}_{2}$-coated glass substrates elaborated by reactive RF-sputtering are investigated. As pathogenic bacteria in biofilms are a major concern in food industries due to their growing resistance to cleaning and sanitizing procedures, the development of photoactive surfaces exhibiting bactericidal properties is acknowledged as an This article has been accepted for publication and undergone full peer review but has not been through the copyediting, typesetting, pagination and proofreading process, which may lead to differences between this version and the Version of Record.
\end{abstract}


effective approach to tackle bacterial contaminations. Our principal aim concerns the study of the photoactive top-layer thickness impact (from $80 \mathrm{~nm}$ to $\sim 500 \mathrm{~nm}$ ) on Listeria monocytogenes. Structural characterization of the $\mathrm{TiO}_{2}$ layers demonstrates that anatase and rutile phases are both present, depending on the film thickness. Photocatalytic activity of the samples has been evaluated through the degradation of aqueous methylene blue (MB) solutions under UVA light illumination for various time periods. The results show an efficiency rating increase according to $\mathrm{TiO}_{2}$ film thickness up to a threshold value close to $400 \mathrm{~nm}$. Moreover a significant decrease of the adherent bacteria number is observed after 20 min of UVA illumination. The quantitative study of the bactericidal activity associated with scanning electron microscopy observations of the post-process bacteria damaged cells demonstrates the efficiency of the $240 \mathrm{~nm}$-thick $\mathrm{TiO}_{2}$ coating sample. The results are correlated with the production of hydroxyl radical during the process of photocatalysis.

\section{INTRODUCTION}

In food industry environments microbial, biofilms grown on work surfaces are the source of contamination, food-borne infections and also equipment damages $(1,2)$. Biofilms represent therefore a recurrent economic and food safety problem. It appears difficult to remove a biofilm once it is formed on food plant surfaces. Indeed the complex biofilm structure protects bacteria from classic disinfection and sanitizing procedures (3-7). Some bacteria, such as Listeria monocytogenes, can persist in various food plant environments from months to several years even when appropriate hygienic measures are applied $(8,9)$. Reis-Teixeira and coworkers have demonstrated that although L. monocytogenes is not able to form thick multilayer biofilms, the cells can persist on abiotic surfaces (10). This result confirms the need to focus on measures or techniques to avoid biofilm formation, instead of trying to fight against mature biofilms. Deposition of semiconductor materials in thin coatings is an efficient way of biologically active and selfsanitizing surface preparation. Antibacterial activity of such top-layers is photoinduced through the 
formation of reactive oxygen species (ROS) when irradiated by light energy higher than the band gap value (11). Among chemically stable, non-toxic and cost-effective materials, titanium dioxide $\left(\mathrm{TiO}_{2}\right)$ has been widely studied as semiconducting oxide for a large range of photocatalytic applications (12). $\mathrm{TiO}_{2}$ material exhibits different polymorphic phases: anatase, rutile and brookite. Rutile is thermodynamically stable, while anatase and brookite phases are in metastable states (13). Among the three crystalline phases, anatase presents the highest photocatalytic and bactericidal activity $(14,15)$. When $\mathrm{TiO}_{2}$ is irradiated by UV light, it produces pairs of electrons and holes. These either recombine, or migrate to the surface of the catalyst where they can participate in oxidation and reduction reactions by generating strong oxidative radicals (hydroxyl radicals, superoxide anions and hydrogen peroxide) that decompose organic compounds (16-18). Therefore, $\mathrm{TiO}_{2}$ can be used as a photocatalytic antibacterial material: it combines chemical stability, biocompatibility and high potential for self-cleaning. That way, $\mathrm{TiO}_{2}$-assisted photocatalytic disinfection, purification or cleanup processes have been evaluated on a wide range of organisms, including viruses, bacteria, fungi and algae (19-22).

Photocatalysts are conventionally available in powder form which makes the catalyst particles removal very difficult and expensive once work has been completed. This drawback can be overcome by immobilizing the catalyst onto or as a surface, at the expense of its developed corrugated surface $(16,23)$. $\mathrm{TiO}_{2}$ photocatalytic coatings can be elaborated by various techniques, such as sol-gel process (24), chemical vapor deposition (25) and sputtering deposition methods (26). Radiofrequency (RF) and direct current (DC) sputtering are ones of the most available methods, frequently used in mass production due to their high deposition rates, high reliability, moderate running costs and possibility of covering a large range of substrate types (27). 
In this work, titanium dioxide thin films with various thicknesses were grown by RF magnetron sputtering technique on glass substrates to investigate the effect of the $\mathrm{TiO}_{2}$ film thickness on the photocatalytic and bactericidal activities. Transparent substrates have been especially selected in the present study to extract the intrinsic optical characteristics of the photoactive coatings. The elaborated samples have been tested against the relevant food-born pathogen L. monocytogenes.

\section{MATERIALS AND METHODS}

Bacterial strain. Two strains of $L$. monocytogenes were considered in the present study: the $L$. monocytogenes ScottA reference strain (28) and the ECL 136 environmental strain sampled in a food plant (29). Each strain was stored at $-70^{\circ} \mathrm{C}$ in Brain Heart Infusion (BHI) broth (Biokar, France) containing $40 \%(\mathrm{v} / \mathrm{v})$ of glycerol. After the strain culture on Plate Count Agar (PCA) for 18 hours at $37^{\circ} \mathrm{C}$, one colony was placed into $\mathrm{BHI}$ broth for 7 hours, as a pre-culture, at $37^{\circ} \mathrm{C}$. Using the preculture, the appropriate broth was inoculated for an overnight sub-culture. After this, the bacterial suspension concentration was adjusted to $10^{8} \mathrm{CFU} / \mathrm{mL}$ by measuring its optical density at $600 \mathrm{~nm}$, and confirmed by enumeration on BHI. Then $50 \mu \mathrm{L}$ of these suspensions have been loaded onto $\mathrm{TiO}_{2}$ thin film to assess the susceptibility of the strains to UVA $(365 \mathrm{~nm})$ and to measure the bactericidal activity.

$\mathrm{TiO}_{2}$ film elaboration. $\mathrm{TiO}_{2}$ thin films were deposited on $(50 \mathrm{~mm} \times 50 \mathrm{~mm} \times 0.7 \mathrm{~mm})$ soda-lime glass substrates by RF magnetron sputtering technique $(30,31)$. The deposition chamber (Plassys MP 450S) that contained a titanium metal target (100.4 mm diameter, $99.995 \%$ purity) was pumped down to $5 \times 10^{-5} \mathrm{~Pa}$ by a turbomolecular rotary pump system. The distance between the target and the substrate was set at $80 \mathrm{~mm}$. Glass substrates were first cleaned in an alkaline lye at $60^{\circ} \mathrm{C}$ for 15 min, rinsed copiously with deionized water $(10 \mathrm{~min})$ and dried under a steam of dry nitrogen. The 
glass substrate, clamped on a sample holder, was then introduced in the deposition chamber via a loadlock chamber. The titanium target was supplied with RF power through an automatic matching network. Before each deposition step, the target was pre-sputtered in pure argon (Ar) atmosphere (2.75 Pa) under $50 \mathrm{~W}$ RF power for 10 min to remove any target surface contaminates. Then a mixture of argon ( $\mathrm{Ar})$ and oxygen $\left(\mathrm{O}_{2}\right)$ gas was bled into the sputtering chamber and adjusted by two mass flow controllers. The different parameters during $\mathrm{TiO}_{2}$ deposition were set as follows: $\mathrm{RF}$ power: $200 \mathrm{~W}$, substrate temperature: $440^{\circ} \mathrm{C}, \mathrm{O}_{2} /$ Ar volume ratio: $3 \%$ and working pressure: 2.75 Pa. In order to obtain different film thicknesses, six deposition times: 60, 120, 180, 240, 300 and 360 min were used. The elaborated films are denoted in the present paper by $\mathrm{TiO}_{2}$-film thickness, such as $\mathrm{TiO}_{2}-80 \mathrm{~nm}$ (film thickness $\mathrm{d}=80 \mathrm{~nm}$ and sputtering time $=60 \mathrm{~min}$ ). After deposition, each sample was cleaved into coupons of $1 \mathrm{~cm} \times 1 \mathrm{~cm}$ each.

Physical characterizations of the $\mathrm{TiO}_{2}$ thin films. A standard 4-point probe configuration, with a 225 Keithley current source and a 7050 Schlumberger microvoltmeter, provides the sheet resistance $R_{S}$ at room temperature.

Optical transmittance was recorded by a UV-Visible spectrophotometer (Perkin Elmer Lambda 20 (Waltham, MA, USA), scanning speed $240 \mathrm{~nm} / \mathrm{min}, 2 \mathrm{~nm}$ width slit) in the $200-1100 \mathrm{~nm}$ spectral range at normal incidence. The UV-Visible spectrophotometer was previously calibrated with air (blank). In region of strong absorption, the transmittance of the thin film $\mathrm{T}$ is expressed in terms of absorption coefficient $\alpha$ and film thickness $d$, as follows:

$$
\ln (T)=-\alpha \times d
$$

Taking into account the indirect-allowed transition of the $\mathrm{TiO}_{2}$ band structure (32), the absorption coefficient is expressed by: 


$$
(\alpha h v)^{1 / 2}=A \times(h v-E g)
$$

where $\mathrm{h} v$ is the photon energy, $\mathrm{A}$ is a constant independent of photon energy and Eg is the optical band gap of $\mathrm{TiO}_{2}$. By extrapolating the linear part of $(\alpha h v)^{1 / 2}$ versus energy, Eg value is determined for $(\alpha h v)^{1 / 2}=0$ with an accuracy of $0.05 \mathrm{eV}(33)$.

X-Ray Diffraction (XRD) analyses were performed on a Seifert 3003 PTS diffractometer in $\theta-2 \theta$ mode. A parallel beam configuration was used with a Ge (220) monochromator mounted on the primary beam ( $\mathrm{Cu} \lambda_{\mathrm{k} \alpha 1}=0.154056 \mathrm{~nm}$ ). Data were recorded from $10^{\circ}$ to $80^{\circ}$ with a step angle of $0.01^{\circ}$ and a scan rate of $0.15^{\circ} / \mathrm{min} . \mathrm{TiO}_{2}$ peak indexation has been performed in reference to the joint committee in powder diffraction standards files: 71-1167 for anatase phase and 77-0442 for $\mathrm{TiO}_{2}$ rutile phase.

Surface and cross-section observations were conducted on a Jeol JSM-5600 Scanning Electron Microscope (SEM) operating at $10 \mathrm{kV}$. Thickness of the $\mathrm{TiO}_{2}$ films was measured by SEM crosssectional view on cleaved sections.

Photocatalytic activity of the $\mathrm{TiO}_{2}$ coatings. Photocatalytic activity of the $\mathrm{TiO}_{2}$ coated glass samples under UVA illumination was assessed by the methylene blue (MB) test (34) using a UVA lamp at 365 $\mathrm{nm}, 1350 \mu \mathrm{W} / \mathrm{cm}^{2}$ (Vilbert Lourmat, VWR), for 60 minutes at a distance of $2 \mathrm{~cm}$. Bare glass coupons have been used as negative controls.

Each coupon (coated with or without $\mathrm{TiO}_{2}$ thin film) was placed into a well of a 24-well microplate (Greiner Bio-one, Austria) and loaded with $50 \mu \mathrm{L}$ of a MB solution at $0.002 \%(w / v)$. After UVA illumination, $950 \mu \mathrm{L}$ of saline water $(9 \mathrm{~g} / \mathrm{L} \mathrm{NaCl})$ was added in each well. Absorbance was measured with a visible spectrophotometer (Thermospectronic, Biomate3, France) at $650 \mathrm{~nm}$. The decrease of the optical density before and after UVA illumination evidences the photocatalytic activity of the 
$\mathrm{TiO}_{2}$ thin layers in comparison with negative controls. The photocatalytic activity PA is expressed as the ratio between the relative variation of the absorbance $\left(A-A_{0}\right)$ and the initial absorbance $A_{0}$, as follows:

$$
P A=100 \times\left(A-A_{0}\right) / A_{0}
$$

Bactericidal activity of the $\mathrm{TiO}_{2}$ coatings. For bactericidal activity measurements, coupons of glass (negative controls) and coupons coated with $\mathrm{TiO}_{2}$ thin layers $\left(1 \mathrm{~cm}^{2}\right.$ in size) were placed into wells of a 24-well microplate. Then $50 \mu \mathrm{L}$ of the prepared bacterial suspension were loaded onto the surface of each coupon to obtain an initial load of $5 \times 10^{6}$ bacteria. All coupons were incubated at $20^{\circ} \mathrm{C}$ for 3 hours to provide bacterial adhesion. The incubation was done in a wet atmosphere to avoid any drying effect of the coupons. After the adhesion step, half of the coupons were exposed to UVA radiations ( $365 \mathrm{~nm}, 20 \mathrm{~min}, 2 \mathrm{~cm}$ distance between coupons and UVA lamp); the other coupons were placed in the dark.

The bactericidal activity of the $\mathrm{TiO}_{2}$-coated samples was assessed by two different ways: by enumerating the surviving bacterial cells and by observing the morphology of the cells anchored on the coupon surface by SEM.

For the enumeration of the surviving bacterial cells, coupons with adherent cells were first washed twice with saline solution and placed in $2 \mathrm{~mL}$ of saline solution for sonication at $47 \mathrm{kHz}$ for $20 \mathrm{~min}$ (Ultrasonic Bath 3210, Branson, USA) to take off adherent cells. Cultivable cells were then enumerated on $\mathrm{BHI}$ agar plates after 48 hours at $37^{\circ} \mathrm{C}$.

The decadic logarithm of reduction, i.e. $\log \left(\mathrm{N} / \mathrm{N}_{0}\right)$ was computed, where $\mathrm{N}_{0}$ is the number of bacteria deposited onto coupons expressed in CFU, and $\mathrm{N}$ is the number of cultivable bacteria after treatment expressed in CFU. 
For the morphology observation of the cells anchored on the coupon surface by SEM, coupons with adherent cells were immersed in a 3\% glutaraldehyde solution prepared in 0.1M phosphate buffer for 1 hour to allow fixation of the cells. Then coupons were washed twice with saline water and immerged in successive ethanol baths with increasing percentage in vol.: $50 \%, 75 \%$ and $90 \%$ for 5 min each and ethanol at $100 \%$ for 30 min. Finally ethanol was replaced using a hexamethyldisilazane (HMDS) (Sigma-Aldrich, France) gradient at 50\%, 75\% in vol. for $10 \mathrm{~min}$ each and 100\% for $30 \mathrm{~min}$. HMDS is a drying agent and is used as a good alternative to Critical Point Drying for SEM sample preparation (35). At the end, the coupons were dried at room temperature for 24 hours for final SEM observation.

ROS detection. The detection of ROS was performed on coupons of bare glass (negative controls) and coupons coated with $\mathrm{TiO}_{2}$ thin layers $\left(1 \mathrm{~cm}^{2}\right.$ in size). The involvement of hydroxyl radicals ${ }^{\circ} \mathrm{OH}$, has been underlined using the methylene blue degradation test adding mannitol, a scavenger of ${ }^{\circ} \mathrm{OH}$. Coupons were placed into a 24 -well microplate. $50 \mu \mathrm{L}$ of a solution of $\mathrm{MB}(0.002 \%)$ with a solution of $300 \mathrm{mM}$ mannitol were added onto the surface of each coupon. After UVA illumination for $20 \mathrm{~min}$, absorbance of the solution was determined in order to assess the involvement of ${ }^{\circ} \mathrm{OH}$ in the photocatalysis reaction.

Statistical analysis. Statistical tests were carried out by using a two sample Student t-test with the same variance (XL Stats, free version, Addinsoft) and "R" software. Significant differences were indicated for each treatment $(p<0.05)$. 


\section{RESULTS}

\section{Characterization of the $\mathrm{TiO}_{2}$ thin films}

Six $\mathrm{TiO}_{2}$ thin films have been elaborated by RF sputtering according to various deposition times (from 1 to 6 hours) with the same substrate temperature and partial pressure of oxygen in argon (Table 1). An average deposition rate of $1.33 \mathrm{~nm} / \mathrm{min}$ was obtained with the sputtering parameters as reported in Table 1 . The sheet resistance $\left(R_{S}\right)$ of the samples, measured at room temperature, are beyond the measurement range of our setup $\left(R_{S}>5 \times 10^{9} \Omega / s q\right)$. Indeed $\mathrm{TiO}_{2}$ thin film resistivity $(\rho)$ is extremely high, $\rho>10^{6} \Omega . \mathrm{cm}$ (36), leading for the highest thickness ( $d=480 \mathrm{~nm}$ ) to expected sheet resistance values higher than $2 \times 10^{10} \Omega / \mathrm{sq}$. Those values put $\mathrm{TiO}_{2}$ on the borderline between semiconductors and insulators.

The $\mathrm{TiO}_{2}$ phases were identified by XRD. Figure 1 presents the XRD patterns according to the $\mathrm{TiO}_{2}$ films thickness. On the one hand, a permanent signature of the anatase phase (main peak at $2 \theta=$ $25.271^{\circ}$ that corresponds to the (101) orientation appears on all diffraction patterns. On the other hand, the rutile phase is observed on the thicker films ( $d$ higher than $240 \mathrm{~nm}$ ). From a $\mathrm{TiO}_{2}$ thickness of $400 \mathrm{~nm}$, the contributions of the rutile and anatase phases on XRD patterns are qualitatively similar.

Figure 2 shows the surface morphology of the $\mathrm{TiO}_{2}$ thin films observed by SEM according to the film thickness. SEM images exhibit uniform distribution of submicron-sized grains and are crack free.

To assess the optical properties of the $\mathrm{TiO}_{2}$ films, optical transmission spectra of the samples have been recorded in air (data not shown) and the band gaps Eg have been computed. Eg values of the thinner films are slightly higher than that of the thicker films. On thin films, as the reported bandgap values of the pure anatase and rutile phases are in the range [3.3 - 3.2 eV] and [3.1 - 3.0 eV] 
respectively $(32,37-41)$, the decrease of the optical band gap versus the thickness supports the phase variation from anatase to rutile, as observed on the XRD patterns (Figure 1).

\section{Photocatalytic properties of the $\mathrm{TiO}_{2}$ coatings}

The decrease of the methylene blue absorbance at $650 \mathrm{~nm}$ according to illumination time is presented in Figure 3. The six $\mathrm{TiO}_{2}$ thin films exhibit a significant $\mathrm{MB}$ discoloration rate after $60 \mathrm{~min}$ of UVA illumination (Student test; $p<0$.) compared with both samples without UVA activation and the bare glass substrate (Figure 3A). An exponential decrease is observed and suggests first-order kinetics. According to the $-\ln \left(A / A_{0}\right)=k t$ equation, a straight line is fitted to the data and the apparent first-order constant $\mathrm{k}$ is retrieved from the slope (Figure 3B). As the $\mathrm{TiO}_{2}$ thin film thickness increases, the MB discoloration rate increases too. The degradation rate saturates above the 400 $\mathrm{nm}$ film thickness value.

\section{Bactericidal properties of the $\mathrm{TiO}_{2}$ coatings}

The antibacterial tests were carried out on the two strains of $L$. monocytogenes to determine the inactivation performance of the $\operatorname{six} \mathrm{TiO}_{2}$ coatings grown on glass substrates. The results of bactericidal assays, with and without UVA illumination, and using the bare glass substrate as negative control, are presented in Figure 4. The measurements undertaken on the bare glass substrate exhibit no significant bactericidal effect on both strains of L. monocytogenes in the dark and under UVA illumination (Figure 4). 
Without UVA radiation, the number of adherent cells is similar over all samples, on the bare glass coupons as well as on the $\mathrm{TiO}_{2}$ coatings whatever their thickness. On both strains, the difference in the bacteria natural ability to survive on the bare glass substrate, with or without UVA illumination, is not significant (Student test, $\mathrm{p}>0.05$ ). The bacteria adhesion on the coupons is not any more affected by the $\mathrm{TiO}_{2}$ coatings, as shown by the measurements in the dark (Figure 4).

After photoactivation with UVA radiations for $20 \mathrm{~min}, \mathrm{TiO}_{2}$ coatings as a whole provide a strong bactericidal effect on both strains. On L. monocytogenes ScottA (Figure 4 A), the number of adherent bacteria decreases gradually with the increase of the $\mathrm{TiO}_{2}$ thickness. That way, a reduction in the number of surviving cells of $2.5 \mathrm{log}$ is obtained with the $480 \mathrm{~nm}$-thick $\mathrm{TiO}_{2}$ coating. On L. monocytogenes ECL136 (Figure 4 B), the photocatalytic efficiency of the active coating increases from the first few tens of nanometer and reaches a saturation point with a $\mathrm{TiO}_{2}$ thickness close to $240 \mathrm{~nm}$, corresponding to a similar efficiency $(2.5 \mathrm{log})$ measured on the previous reference strain with the thicker $\mathrm{TiO}_{2}$ coating $(\mathrm{d} \approx 500 \mathrm{~nm}$ ) (Figure 5).

The cells of both strains, environmental and reference strains adhering onto the $\mathrm{TiO}_{2}-240 \mathrm{~nm}$ coupon surface and onto the bare glass surface were exposed to UVA radiations for 20 min and were observed by SEM. Damaged cells occur on the functionalized surface after UVA activation, by contrast to those adhering on the bare glass coupons and showing no apparent morphological damages (Figure 6). Damaged cells appear empty without cytoplasmic content as "ghost cells", with some membranes drilled. Indeed, UVA illumination could be responsible for DNA mutation and death cell if UV exposure is long. In our case, we used UVA wavelength, the less damaging UV rays $(\lambda=365 \mathrm{~nm})$ for a maximum time of $20 \mathrm{~min}$.

All these observations have been correlated with the results of ROS detection. The involvement of - $\mathrm{OH}$ in methylene blue degradation has been confirmed with the $\mathrm{TiO}_{2}-240 \mathrm{~nm}$ sample (Figure 7). After UVA illumination, $\mathrm{TiO}_{2}$ coupons exhibit a $\mathrm{MB}$ discoloration. When mannitol is added to the $\mathrm{MB}$ 
solution, no MB discoloration has been observed. The absorbance spectra of the MB solution after UVA illumination was the same as the absorbance observed with the bare glass coupons, showing that ${ }^{\bullet} \mathrm{OH}$ scavenger presence has enabled to achieve the absorbance of the negative control.

\section{DISCUSSION}

In the present study, glass substrates have been functionalized by RF sputtering deposition of $\mathrm{TiO}_{2}$ thin films. Influence of the $\mathrm{TiO}_{2}$ thickness on the photocatalytic and bactericidal activities has been investigated. Thin layers have been obtained from deposition time of 1 hour up to 6 hours, and thickness is linearly correlated to deposition time with $\mathrm{TiO}_{2}$ thin layers varying from $80 \mathrm{~nm}$ to 480 $\mathrm{nm}$ respectively. The deposition rate of $80 \mathrm{~nm}$ per hour is currently observed when using RF magnetron sputtering deposition for $\mathrm{TiO}_{2}$ thin films (42). As the film thickness increases, the surface morphology changes. Heikkilä and co-workers, in 2009, concluded that grains and surface roughness increase toward the $\mathrm{TiO}_{2}$ film thickness (23).

Using our sputtering parameters, $\mathrm{TiO}_{2}$ thin films exhibit an anatase structure at low thicknesses (d thinner than $\sim 240 \mathrm{~nm}$ ) whereas the crystalline phase evolves toward a combination of anatase and rutile structures with the thicker films. Such dual structure could help to achieve a better efficiency in bactericidal activity. Indeed many studies have previously underlined a higher photocatalytic performance in a wide range of applications (self-cleaning surfaces, air and water purification, $\mathrm{H}_{2}$ production by water splitting...) when $\mathrm{TiO}_{2}$ provides a mixture of anatase and rutile structures (43) at a specific [anatase : rutile] ratio in the range $[70: 30-80: 20]$ respectively, as found in the commercially available titania photocatalyst Degussa P25 $(14,15,44)$. In that case, the efficiency of the UV-driven organic pollutants photocatalytic oxidation is enhanced by the existence of nanoscale 
heterojunctions between the anatase and the rutile phases (45-46). In this context, on powder or on mesoporous nanofibers, those multi-semiconductor/semiconductor junctions between the $\mathrm{TiO}_{2}$ polymorphs modify the band-gap structure and consequently the photocatalytic activity of the material. Concerning the bactericidal performance under UV light, while anatase-type $\mathrm{TiO}_{2}$ powders or thin films always exhibit an antibacterial activity on various types of bacteria (47-50), rutile-type titanium dioxide phase demonstrates no bactericidal activity $(15,16,48,51)$ unless the film is fully $\{111\}$-oriented (52). Conversely, under the visible light, while the detrimental effect of the anatase phase on the survival of the bacteria is non-existent (53) or limited (54), the rutile structure takes over the activity (53-55). As the rutile phase exhibits a lower band-gap value than that of the anatase, its ability to use the blue part of the visible spectrum explains in part this behaviour. Moreover, ROS types, natures and quantities depend on both titanium dioxide structure and radiation wavelengths. That way, it has been shown that under UV illumination, the activity of anatase materials is primarily related to the efficient production of $\bullet \mathrm{OH}$ species (56) while visible light illumination largely enhances $\bullet \mathrm{O}_{2}$ - formation on rutile surfaces $(51,56)$. One must also keep in mind that the exact composition of the ROS mixture formed as well as its reactivity depends not only on the structure and texture of the photocatalyst, but also on the bacteria-type itself. In the present study, $\mathrm{TiO}_{2}$ coatings thicker than $240 \mathrm{~nm}$, composed of anatase and rutile phases, exhibit the best photocatalytic and bactericidal activities. The kinetic data retrieved from the photocatalytic degradation of MB can be correlated with the bactericidal performance. The photocatalytic activity of our $\mathrm{TiO}_{2}$ coatings with thicknesses up to $400 \mathrm{~nm}$, allowed more than $90 \%$ of $\mathrm{MB}$ discoloration in one hour. Commercial Degussa P25 $5^{\circ}$, tested by Barnes and co-workers in 2013 , provided $76 \%$ of discoloration rate after one hour exposure under UVA radiations at $365 \mathrm{~nm}$ (57). Moreover Heikkilä and co-workers also grew $\mathrm{TiO}_{2}$ thin films by Atomic Layer Deposition (ALD) technique (23). Their anatase- $\mathrm{TiO}_{2}$ films with various thicknesses (from 50 to $520 \mathrm{~nm}$ ) caused MB discoloration, around 10\% after 1 hour-UVA irradiation. As we observed above, Heikkilä and co-workers showed an exponential decrease which suggests first-order kinectics. Initial MB concentration, temperature, 
$\mathrm{TiO}_{2}$ concentration and form, illumination wavelength have been shown to influence the photocatalytic activity and especially the kinetics rate (58). Comparison of kinetics rate is therefore difficult because of the spread in the initial settings.

$\mathrm{TiO}_{2}$ photocatalysts as fine particles have already been studied to fight against bacteria in various environments such as medical environments (59-60), water disinfection field (61-64) or food plants $(19,20)$. However, the use of $\mathrm{TiO}_{2}$ suspension presents a disadvantage in the postcatalytic catalyst removal $(17,65)$. In food plants, an alternative way concerns the development of stable coatings through thin film deposition. In the present work, RF magnetron sputtering technique has been used to grow $\mathrm{TiO}_{2}$ thin films with different thicknesses. This type of functionalized materials aims to restrict the first step of biofilm formation by preventing the bacteria adhesion. For this purpose, the $\mathrm{TiO}_{2}$ thin films have been tested against adherent $L$. monocytogenes bacteria and not against mature biofilms $(19,66)$. Unfortunately, these $\mathrm{TiO}_{2}$ coatings do not provide any anti-adhesive property, since no difference has been observed between the number of bacteria grown on the bare glass substrates and those grown on the $\mathrm{TiO}_{2}$ coatings without UVA illumination. Similarly Chorianopoulos and co-workers did not obtain any anti-adhesive effect on the L. monocytogenes ScottA bacteria grown onto glass coated with $\mathrm{TiO}_{2}$ layers, without UVA irradiation (19).

After UVA activation of the $\mathrm{TiO}_{2}$ layers, the surfaces present a strong bactericidal activity against both L. monocytogenes strains. This bactericidal effect can be related to the thickness of the $\mathrm{TiO}_{2}$ layer and also to the $\mathrm{TiO}_{2}$ crystalline phase as depicted in Figure 5. Indeed the presence of the rutile phase in addition to the anatase one in $\mathrm{TiO}_{2}$ films thicker than $240 \mathrm{~nm}$ seems to be linked to the saturation effect undergone by the environmental strain L. monocytogenes ECL136. 
Active species (ROS) are produced by the photocatalytic $\mathrm{TiO}_{2}$ coating. Concerning our $\mathrm{TiO}_{2}$ coupons, hydroxyl radical production may be involved in the bactericidal activity. The use of mannitol as a scavenger highlighted the ${ }^{\circ} \mathrm{OH}$ involvement in the $\mathrm{MB}$ discoloration, and thus in the photocatalytic activity. Other detection methods such as electron spin resonance observation, direct fluorescence or chemiluminescence exist. These methods are quantitative and accurate. However these methods require specific and expensive equipments to be performed (18). ROS as ${ }^{\circ} \mathrm{OH}$ affect the cell wall integrity as observed by SEM, while direct UVA radiations do not affect their cell morphology. Indeed UV radiations may damage DNA and cause mutations (67). UV resistance of bacteria differs between species and also depends on the age of organisms, growth stage and also bacterial form (biofilm or adherent cells) $(31,68,69)$. In general, Gram-positive bacteria tend to be more resistant to UV radiations than Gram-negative bacteria $(31,67)$.

Listeria monocytogenes ScottA and ECL136 belong to the serotypes $4 \mathrm{~b}$ and 1/2a, respectively. The observed differences in susceptibility may be related to variable responses to oxidative stress as it was highlighted in a recent study (70). Moreover the composition of the teichoic acids is different between $4 \mathrm{~b}$ and $1 / 2 \mathrm{a}$ serotype $(71,72)$. The wall components are known to be a target of the ROS generated by the $\mathrm{TiO}_{2}$. Consequently this may contribute to the difference in susceptibility of the two Listeria strains

In conclusion, $\mathrm{TiO}_{2}$ coatings deposited by $\mathrm{RF}$ sputtering technique on glass substrates and activated by UVA illumination exhibit bactericidal activity against the foodborne pathogen L. monocytogenes. Indeed a significant reduction of the adherent cells after 20 min of UVA exposure has been measured. $240 \mathrm{~nm}$-thick $\mathrm{TiO}_{2}$ coating is sufficient to promote optimal bactericidal activity against $L$. monocytogenes ECL316 whereas thicker films ( $\sim 500 \mathrm{~nm})$ are needed against L. monocytogenes ScottA. The $\mathrm{TiO}_{2}$ surface functionalization paves the way to improve cleanability and disinfection in . 
food industry environments. Work is under progress to grow such $\mathrm{TiO}_{2}$ thin films onto stainless steel substrates in order to be applied in food plants.

\section{ACKNOWLEDGEMENTS}

This work was supported by the European Union through the European Regional Development Fund (ERDF), and by the Ministry of Higher Education and Research, the French region of Brittany, through the CPER Projects 2015-2020 MATECOM and SOPHIE/STIC \& Ondes. This work was also supported by a grant from Saint-Brieuc Armor Agglomération and the Département des Côtes d'Armor. We thank Stéphanie Bougeard for her help in statistical analysis, Maël Visdeloup and Nyedna Policarpo for their technical support.

\section{REFERENCES}

1. Trachoo N. 2003. Biofilms and the food industry. Songklanakarin J. Sci. Technol. 25(6):807815

2. Abdallah M, Benoliel C, Drider D, Dhulster P, Chihib N-E. 2014. Biofilm formation and persistence on abiotic surfaces in the context of food and medical environments. Arch. Microbiol. 196(7):453-472

3. Gil MI, Selma MV, López-Gálvez F, Allende A. 2009. Fresh-cut product sanitation and wash water disinfection: problems and solutions. Int. J. Food Microbiol. 134(1-2):37-45 
4. Ibusquiza PS, Herrera JJR, Cabo ML. 2011. Resistance to benzalkonium chloride, peracetic acid and nisin during formation of mature biofilms by Listeria monocytogenes. Food Microbiol. 28(3):418-425

5. Soumet C, Méheust D, Pissavin C, Le Grandois P, Frémaux B, Feurer C, Le Roux A, Denis M, Maris P. 2016. Reduced susceptibilities to biocides and resistance to antibiotics in food-associated bacteria following exposure to quaternary ammonium compounds. J. Appl. Microbiol. 121(5):12751281

6. Colagiorgi A, Di Ciccio P, Zanardi E, Ghidini S, lanieri A. 2016. A Look inside the Listeria monocytogenes biofilms extracellular matrix. Microorganisms. 4(3):1-12

7. Pilchova T, Hernould M, Prévost H, Demnerova K, Pazlarova J, Tresse O. 2014. Influence of food processing environments on structure initiation of static biofilm of Listeria monocytogenes. Food Control. 35:366-372

8. Bridier A, Sanchez-Vizuete P, Guilbaud M, Piard J-C, Naïtali M, Briandet R. 2015. Biofilmassociated persistence of food-borne pathogens. Spec. Issue Predict. Model. Food. 45, Part B:167178

9. Carpentier B, Cerf O. 1993. Biofilms and their consequences, with particular reference to hygiene in the food industry. J Appl Bacteriol. 75(6):499-511

10. Reis-Teixeira FB, Alves VF, de Martinis ECP. 2017. Growth, viability and architecture of biofilms of Listeria monocytogenes formed on abiotic surfaces. Braz. J. Microbiol.48(3) :587-591.

11. Joost $U$, Juganson $K$, Visnapuu $M$, Mortimer M, Kahru A, Nõmmiste E, Joost U, Kisand V, Ivask A. 2015. Photocatalytic antibacterial activity of nano- $\mathrm{TiO}_{2}$ (anatase)-based thin films: Effects on Escherichia coli cells and fatty acids. J. Photochem. Photobiol. B. 142(Supplement C):178-185 
12. Nakata K, Fujishima A. 2012. $\mathrm{TiO}_{2}$ photocatalysis: Design and applications. J. Photochem. Photobiol. C Photochem. Rev. 13:169-189

13. Gopal M, Chan WJM, Jonghe LCD. 1997. Room temperature synthesis of crystalline metal oxides. J. Mater. Sci. 32(22):6001-6008

14. Navabpour P, Cooke K, Sun H. 2017. Photocatalytic properties of doped $\mathrm{TiO}_{2}$ coatings deposited using reactive magnetron sputtering. Coatings. 7(1):433-449

15. Sirimahachai U, Phongpaichit S, Wongnawa S. 2009. Evaluation of bactericidal activity of $\mathrm{TiO}_{2}$ photocatalysts: a comparative study of laboratory-made and commercial $\mathrm{TiO}_{2}$ samples. Songklanakarin J. Sci. Technol. 31(5):517-525

16. Miao L, Tanemura S, Kondo Y, Iwata M, Toh S, Kaneko K. 2004. Microstructure and bactericidal ability of photocatalytic $\mathrm{TiO}_{2}$ thin films prepared by $\mathrm{RF}$ helicon magnetron sputtering. Appl. Surf. Sci. 238(1-4):125-131

17. Ede S, Hafner L, Dunlop P, Byrne J, Will G. 2012. Photocatalytic disinfection of bacterial pollutants using suspended and immobilized $\mathrm{TiO}_{2}$ powders. Photochem. Photobiol. 88(3):728-735

18. Nosaka Y, Nosaka AY. 2017. Generation and detection of reactive oxygen species in photocatalysis. Chem. Rev. 117(17):11302-11336

19. Chorianopoulos NG, Tsoukleris DS, Panagou EZ, Falaras P, Nychas GJ. 2011. Use of titanium dioxide $\left(\mathrm{TiO}_{2}\right)$ photocatalysts as alternative means for Listeria monocytogenes biofilm disinfection in food processing. Food Microbiol. 28(1):164-170

20. Kim B, Kim D, Cho D, Cho S. 2003. Bactericidal effect of $\mathrm{TiO}_{2}$ photocatalyst on selected foodborne pathogenic bacteria. Chemosphere. 52(1):277-281 
21. Thabet S, Weiss-Gayet M, Dappozze F, Cotton P, Guillard C. 2013. Photocatalysis on yeast cells: toward targets and mechanisms. Appl. Catal. B Environ. 140-141:169-78

22. Gogniat G, Thyssen M, Denis M, Pulgarin C, Dukan S. 2006. The bactericidal effect of $\mathrm{TiO}_{2}$ photocatalysis involves adsorption onto catalyst and the loss of membrane integrity. FEMS Microbiol. Lett. 258(1):18-24

23. Heikkilä M, Puukilainen E, Ritala M, Leskelä M. 2009. Effect of thickness of ALD grown $\mathrm{TiO}_{2}$ films on photoelectrocatalysis. J. Photochem. Photobiol. Chem. 204(2-3):200-208

24. Calabria A. J, Vasconcelos WL, Daniel DJ, Chater R, McPhail D, Boccaccini AR. 2010. Synthesis of sol-gel titania bactericide coatings on adobe brick. Constr. Build. Mater. 24(3):384-389

25. Bessergenev VG, Mateus MC, Morgado IM, Hantusch M, Burkel E. 2017. Photocatalytic reactor, CVD technology of its preparation and water purification from pharmaceutical drugs and agricultural pesticides. Chem. Eng. J. 312(Supplement C):306-316

26. Singh J, Khan SA, Shah J, Kotnala RK, Mohapatra S. 2017. Nanostructured $\mathrm{TiO}_{2}$ thin films prepared by RF magnetron sputtering for photocatalytic applications. Appl. Surf. Sci.

422(Supplement C):953-961

27. Ferraris S, Perero S. 2016. 2 - Smart and composite inorganic coatings obtained by sputtering: a promising solution for numerous application fields. Smart Composite Coatings and Membranes, ed MF Montemor, pp. 33-60. Woodhead Publishing

28. Fleming DW, Cochi SL, MacDonald KL, Brondum J, Hayes PS, Plikaytis B, Holmes M, Audurier A, Broome C, Reingold A.1985. Pasteurized milk as a vehicle of infection in an outbreak of Listeriosis. N. Engl. J. Med. 312(7):404-407 
29. Chasseignaux E, Gérault P, Toquin M-T, Salvat G, Colin P, Ermel G. 2002. Ecology of Listeria monocytogenes in the environment of raw poultry meat and raw pork meat processing plants. FEMS Microbiol. Lett. 210(2):271-275

30. Le Paven C, Le Gendre L, Benzerga R, Cheviré F, Tessier F, Jacq S, Traoré-Mantion S, Sharaiha A. 2015. Growth of (Sr,La)-(Ta,Ti)-O-N perovskite oxide and oxynitride films by radiofrequency magnetron sputtering: Influence of the reactive atmosphere on the film structure. J. Cryst. Growth. 413:5-11

31. Barthomeuf M, Raymond P, Policarpo N, Castel X, Le Gendre L, Denis M, Pissavin C. 2017. Bactericidal efficiency of UVA-active titanium dioxide thin layers on bacteria from food industry environments. Mater. Technol. Adv. Perform. Mater. 32(13): 782-791

32. Tang H, Prasad K, Sanjinès R, Schmid PE, Lévy F. 1994. Electrical and optical properties of $\mathrm{TiO}_{2}$ anatase thin films. J. Appl. Phys. 75:2042-2047

33. Barka-Bouaifel F, Makaoui K, Jouan P-Y, Castel X, Bezzi N, Boukherroub R, Szunerits S. 2012. Preparation and photocatalytic properties of quartz/gold nanostructures $/ \mathrm{TiO}_{2}$ lamellar structures. RSC Adv. 2(32):12482-12488

34. Fu P, Luan Y, Dai X. 2004. Preparation of activated carbon fibers supported $\mathrm{TiO}_{2}$ photocatalyst and evaluation of its photocatalytic reactivity. J. Mol. Catal. - Chem. 221(1):81-88

35. Hazrin-Chong NH, Manefield M. 2012. An alternative SEM drying method using hexamethyldisilazane (HMDS) for microbial cell attachment studies on sub-bituminous coal. J. Microbiol. Methods. 90(2):96-99

36. Casoti D, Orsini V, di Bona A, Gardonio S, Fanetti M, Valant M, Valeri S. 2018. Ageing effects on electrical resistivity of $\mathrm{Nb}$-doped $\mathrm{TiO}_{2}$ thin films deposited at a high rate by reactive $\mathrm{DC}$ magnetron sputtering. Appl. Surf. Sci. 455:267-275 
37. Aarik J, Aidla A, Kiisler A-A, Uustare T, Sammelselg V. 1997. Effect of crystal structure on optical properties of $\mathrm{TiO}_{2}$ films grown by atomic layer deposition. Thin Solid Films. 305(1):270-273

38. Daude N, Gout C, Jouanin C. 1977. Electronic band structure of titanium dioxide. Phys. Rev. B. 15(6):3229-3235

39. Camps E, Castrejon-Sanchez VH, Camacho-Lopez M, Basurto R. 2015. Influence of the nitriding process on the band-gap of $\mathrm{TiO}_{2}$ thin films with phase mixture. Thin Solid Films. 581:54-58 40. Long H, Chen A, Yang G, Li Y, Lu P. 2009. Third-order optical nonlinearities in anatase and rutile $\mathrm{TiO}_{2}$ thin films. Thin Solid Films. 517(19):5601-5604.

41. Liu HY, Huang RC. 2018. A study of anatase $\mathrm{TiO}_{2}$-based thin film phototransitors by nonvacuum thin film deposition method. IEEE Trans. Electron Devices. 65(6):2517-2524

42. Nair PB, Justinvictor VB, Daniel GP, Joy K, James Raju KC, Devraj K, Thomas P. 2014. Optical parameters induced by phase transformation in $\mathrm{RF}$ magnetron sputtered $\mathrm{TiO}_{2}$ nanostructured thin films. Prog. Nat. Sci. Mater. Int. 24(3):218-225

43. Yuangpho N, Le STT, Treerujiraphapong T, Khanitchaidecha W, Nakaruk A. 2015. Enhanced photocatalytic performance of $\mathrm{TiO}_{2}$ particles via effect of anatase-rutile ratio. Phys. E Low-Dimens. Syst. Nanostructures. 67(Supplement C):18-22

44. Van der Meulen T, Mattson A, Österlund L. 2007. A comparative study of the photocatalytic oxidation of propane on anatase, rutile, and mixed-phase anatase-rutile $\mathrm{TiO}_{2}$ nanoparticles: Role of surface intermediates. J. Catal. 251(1):131-144

45 Ghosh M, Lohrasbi M, Chuang SSC, Jana SC. 2016. Mesoporous titanium dioxide nanofibers with a significantly enhanced photocatalytic activity. Chem. Cat. Chem. 8:2525-2535 46 Bickley RI, Gonzalez-Carreno T, Lees JS, Palmisano L, Tilley RJD. 1991. A structural 
investigation of titanium dioxide photocatalysts. J. Solid State Chem. 92:178-190

47. Cheng TC, Yao KS, Yeh N, Chang Cl, Hsu HC, Gonzales F, Chang CY. 2011. Bactericidal effect of blue LED light irradiated $\mathrm{TiO}_{2} / \mathrm{Fe}_{3} \mathrm{O}_{4}$ particles on fish pathogen in seawater. Thin Solid Films. 519(15):5002-5006

48. Joo H-C, Lim Y-J, Kim M-J, Kwon H-B, Han J-H. 2010. Characterization on titanium surfaces and its effect on photocatalytic bactericidal activity. Appl. Surf. Sci. 257(3):741-746

49. Sisti L, Cruciani L, Totaro G, Vannini M, Berti C, Tobaldi DM, Tucci A, Aloisio I, Di Gioia D, Commereuc S. 2012. $\mathrm{TiO}_{2}$ deposition on the surface of activated fluoropolymer substrate. Thin Solid Films. 520:2824-2828

50. Lee HU, Lee SC, Lee SM, Lee JW, Kim HJ, Lee J. 2013. Improved photocatalytic and antibacterial activities of three-dimensional polycrystalline anatase $\mathrm{TiO}_{2}$ photocatalysts. Appl. Catal. Gen. 467:394-99

51. Perelshtein I, Applerot G, Perkas N, Grinblat J, Gedanken A. 2012. A one-step process for the antimicrobial finishing of textiles with crystalline $\mathrm{TiO}_{2}$ nanoparticles. Chem. Weinh. Bergstr. Ger. 18(15):4575-4582

52. Liu X, Zhang H, Liu C, Chen J, Li G, An T, Wong PK, Zhao H. 2014. UV and visible light photoelectrocatalytic bactericidal performance of $100 \%\{111\}$ faceted rutile $\mathrm{TiO}_{2}$ photoanode. Catal. Today. 224:77-82

53. Veréb G, Manczinger L, Bozsó G, Sienkiewicz A, Forró L, Mogyorosi K, Hernadi K, Dombi A. 2013. Comparison of the photocatalytic efficiencies of bare and doped rutile and anatase $\mathrm{TiO}_{2}$ photocatalysts under visible light for phenol degradation and E. coli inactivation. Appl. Catal. B Environ. 129:566-574 
54. Rincon AG, Pulgarin C. 2003. Photocatalytical inactivation of E. coli: effect of (continuousintermittent) light intensity and of (suspended-fixed) $\mathrm{TiO}_{2}$ concentration. Appl. Catal. B-Environ. 44(3):263-284

55. Kim C-H, Lee E-S, Kang S-M, de Josselin de Jong E, Kim B-I. 2017. Bactericidal effect of the photocatalystic reaction of titanium dioxide using visible wavelengths on Streptococcus mutans biofilm. Photodiagnosis Photodyn. Ther. 18:279-283

56. Zoltan T, Rosales MC, Yadarola C. 2016. Reactive oxygen species quantification and their correlation with the photocatalytic activity of $\mathrm{TiO}_{2}$ (anatase and rutile) sensitized with asymmetric porphyrins. J. Environ. Chem. Eng. 4(4):3967-3980

57. Barnes RJ, Molina R, Xu J, Dobson PJ, Thompson IP. 2013. Comparison of $\mathrm{TiO}_{2}$ and $\mathrm{ZnO}$ nanoparticles for photocatalytic degradation of methylene blue and the correlated inactivation of gram-positive and gram-negative bacteria. J. Nanoparticle Res. 15(2):1-11

58. Wu C-H, Chern J-M. 2006. Kinetics of photocatalytic decomposition of methylene blue. Ind. Eng. Chem. Res. 45(19):6450-6457

59. Campoccia D, Montanaro L, Arciola CR. 2013. A review of the biomaterials technologies for infection-resistant surfaces. Biomaterials. 34(34):8533-8554

60. Yoshinari M, Oda Y, Kato T, Okuda K. 2001. Influence of surface modifications to titanium on antibacterial activity in vitro. Biomaterials. 22(14):2043-2048

61. Claro EMT, Bidoia ED, de Moraes PB. 2016. A high-performance doped photocatalysts for inactivation of total coliforms in superficial waters using different sources of radiation. J. Environ. Manage. 177:264-270 
62. Fisher MB, Keane DA, Fernández-Ibáñez P, Colreavy J, Hinder SJ, McGuigan KG, Pillai SC, 2013. Nitrogen and copper doped solar light active $\mathrm{TiO}_{2}$ photocatalysts for water decontamination. Appl. Catal. B Environ. 130-131:8-13

63. Kaan CC, Aziz AA, Ibrahim S, Matheswaran M, Saravanan P. 2012. Heterogeneous photocatalytic oxidation an effective tool for wastewater treatment - A review. Studies on Wat. Manag. Issues, InTech, 219-236

64. Robertson JMC, J. Robertson PK, Lawton LA. 2005. A comparison of the effectiveness of $\mathrm{TiO}_{2}$ photocatalysis and UVA photolysis for the destruction of three pathogenic micro-organisms. J. Photochem. Photobiol. Chem. 175(1):51-56

65. Guillard C, Kartheuser B, Lacombe S. 2011. La photocatalyse : dépollution de l'eau ou de l'air et matériaux autonettoyants. Tech. Ing. Génie Procédés Prot. Environ. Base documentaire : TIB327DUO.

66. Carré G, Hamon E, Ennahar S, Estner M, Lett M-C, Horvatovich P, Gies JP, Keller V, Keller N, and Andre P. 2014. $\mathrm{TiO}_{2}$ Photocatalysis damages lipids and proteins in Escherichia coli. Appl. Environ. Microbiol. 80(8):2573-2581

67. Gailunas KM, Matak KE, Boyer RR, Alvarado CZ, Williams RC, Sumner SS. 2008. Use of UV light for the inactivation of Listeria monocytogenes and lactic acid bacteria species in recirculated chill brines. J. Food Prot. 71(3):629-633

68. Bonsaglia ECR, Silva NCC, Fernades Júnior A, Araújo Júnior JP, Tsunemi MH, Rall VLM. 2014. Production of biofilm by Listeria monocytogenes in different materials and temperatures. Food Control. 35(1):386-391 
69. Vázquez-Sánchez D, Cabo ML, Ibusquiza PS, Rodríguez-Herrera JJ. 2014. Biofilm-forming ability and resistance to industrial disinfectants of Staphylococcus aureus isolated from fishery products. Food Control. 39:8-16

70 Huang Y, Morvay AA, Shi X, Suo Y, Shi C, Knøchel S. 2018. Comparison of oxidative stress response and biofilm formation of Listeria monocytogenes serotypes $4 \mathrm{~b}$ and 1/2a. Food Control. 85:416-422

71. Fiedler F, Seger J, Schrettenbrunner A, Seeliger HPR. 1984. The biochemistry of murein and cell wall teichoic acids in the genus Listeria. Syst. Appl. Microbiol. 5:360-376.

72 Promadej N, Fiedler F, Cossart P, Dramsi S, Kathariou S, 1999. Cell wall teichoic acid glycosylation in Listeria monocytogenes Serotype $4 \mathrm{~b}$ requires gtcA, a novel serogroup-specific gene. J. Bacteriol. 181:418-425.

\section{FIGURE CAPTIONS}

Figure 1. X-ray diffraction patterns of a) Bare glass substrate; b) $\mathrm{TiO}_{2}-80 \mathrm{~nm}$; c) $\mathrm{TiO}_{2}-170 \mathrm{~nm}$; d) $\mathrm{TiO}_{2}-240 \mathrm{~nm}$; e) $\mathrm{TiO}_{2}-310 \mathrm{~nm}$; f) $\mathrm{TiO}_{2}-400 \mathrm{~nm}$; g) $\mathrm{TiO}_{2}-480 \mathrm{~nm}$. (•) indicates anatase peaks and $(*)$ indicates rutile peaks.

Figure 2. Surface morphology of the $\mathrm{TiO}_{2}$ thin films observed by Scanning Electron Microscopy (×20 000): (A) $\mathrm{TiO}_{2}-80 \mathrm{~nm}$; (B) $\mathrm{TiO}_{2}-170 \mathrm{~nm}$; (C) $\mathrm{TiO}_{2}-240 \mathrm{~nm}$; (D) $\mathrm{TiO}_{2}-310 \mathrm{~nm}$; (E) $\mathrm{TiO}_{2}-400 \mathrm{~nm}$; (F) $\mathrm{TiO}_{2}-480 \mathrm{~nm}$. 
Figure 3. $\mathrm{TiO}_{2}$ film thickness effect on the photocatalytic discoloration of methylene blue. A) Absorbance of the methylene blue is related to the initial value according to UVA irradiation time. B) Logarithm of the absorbance ratio of methylene blue. First order linear kinetics. The value is a mean of 3 measurements. Bare glass substrate $(\bullet)$; $\mathrm{TiO}_{2}-80 \mathrm{~nm}(\boldsymbol{\mathbf { a }}) ; \mathrm{TiO}_{2}-170 \mathrm{~nm}$

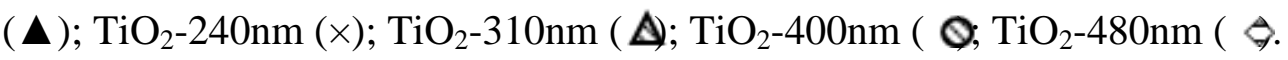

Figure 4. Influence of the $\mathrm{TiO}_{2}$ coatings and UVA illumination on cell viability of 2 bacterial strains A) L. monocytogenes ScottA; B) L. monocytogenes ECL136. Surviving cells are numerated on agar plates, $\mathrm{N}_{0}$ is the cell number deposited onto the coupon and $\mathrm{N}$ is the number of surviving cells after 3 hours and subsequent irradiation or not. Activity of $\mathrm{TiO}_{2}$ under UVA radiations (20 min) ( $\mathbf{a}$ ) is measured and compared with that measured in the dark ( $\square$ ) and with the bare glass (negative control). Data reported here are the mean values of three replicates +/- standard deviation. Means with different lowercase letters differ significantly $(p<0.05)$.

Figure 5. Variation of $\log$ reduction of adherent cells onto $\mathrm{TiO}_{2}$ coatings after UVA activation versus $\mathrm{TiO}_{2}$ thickness. $\mathrm{TiO}_{2}$ phase indication on the figure associates the XRD results. (•) L. monocytogenes ScottA; (•) L. monocytogenes ECL136.

Figure 6. SEM observations $(\times 5000)$ of adherent cells of L. monocytogenes strains. L. monocytogenes ScottA (A, B, C, D) and L. monocytogenes ECL136 (E, F, G, H) onto bare glass substrates in the dark $(\mathrm{A}, \mathrm{E}) ; \mathrm{TiO}_{2}-240 \mathrm{~nm}$ in the dark $(\mathrm{B}, \mathrm{F})$; bare glass substrates after 20 min of UVA illumination $(\mathrm{C}, \mathrm{G})$; $\mathrm{TiO}_{2}-240 \mathrm{~nm}$ after 20 min of UVA illumination $(\mathrm{D}, \mathrm{H})$.

Figure 7. Absorbance spectra of the MB solution coming from the surface of the various coupons after 60 min of UVA illumination. (A) Bare glass substrate. (B) $\mathrm{TiO}_{2}-240 \mathrm{~nm} . \quad \mathrm{MB}$ solution $(0.002 \%)$ MB solution ( $0.002 \%)$ with mannitol $(300 \mathrm{mM})$. 
Table 1. Deposition parameters and characteristics of the $\mathrm{TiO}_{2}$ thin films.

\begin{tabular}{|c|c|c|c|c|c|c|c|}
\hline Layer ID & $\begin{array}{l}\text { Deposition } \\
\text { time (min) }\end{array}$ & $\begin{array}{l}\text { Substrate } \\
\text { temperature } \\
\left({ }^{\circ} \mathrm{C}\right)\end{array}$ & $\begin{array}{l}\mathrm{O}_{2} / \mathrm{Ar} \\
\text { ratio } \\
(\%)\end{array}$ & $\begin{array}{l}\text { Thickness d } \\
\text { (nm) }\end{array}$ & Crystalline phase & $\begin{array}{l}\text { Band } \\
\text { gap EG } \\
\text { (eV) }\end{array}$ & $\begin{array}{l}\text { Photocatalytic activity } \\
\text { (\% of MB discoloration after } \\
60 \text { min of UVA illumination) }\end{array}$ \\
\hline $\mathrm{TiO}_{2}-80 \mathrm{~nm}$ & 60 & 440 & 3 & 80 & Anatase & 3.30 & 23.2 \\
\hline $\mathrm{TiO}_{2}-170 \mathrm{~nm}$ & 120 & 440 & 3 & 170 & Anatase & 3.25 & 36.6 \\
\hline $\mathrm{TiO}_{2}-240 \mathrm{~nm}$ & 180 & 440 & 3 & 240 & Anatase & 3.30 & 50.4 \\
\hline $\mathrm{TiO}_{2}-310 \mathrm{~nm}$ & 240 & 440 & 3 & 310 & Anatase/Rutile & 3.25 & 64.1 \\
\hline $\mathrm{TiO}_{2}-400 \mathrm{~nm}$ & 300 & 440 & 3 & 400 & Anatase/Rutile & 3.15 & 89.1 \\
\hline $\mathrm{TiO}_{2}-480 \mathrm{~nm}$ & 360 & 440 & 3 & 480 & Anatase/Rutile & 3.20 & 87.1 \\
\hline
\end{tabular}




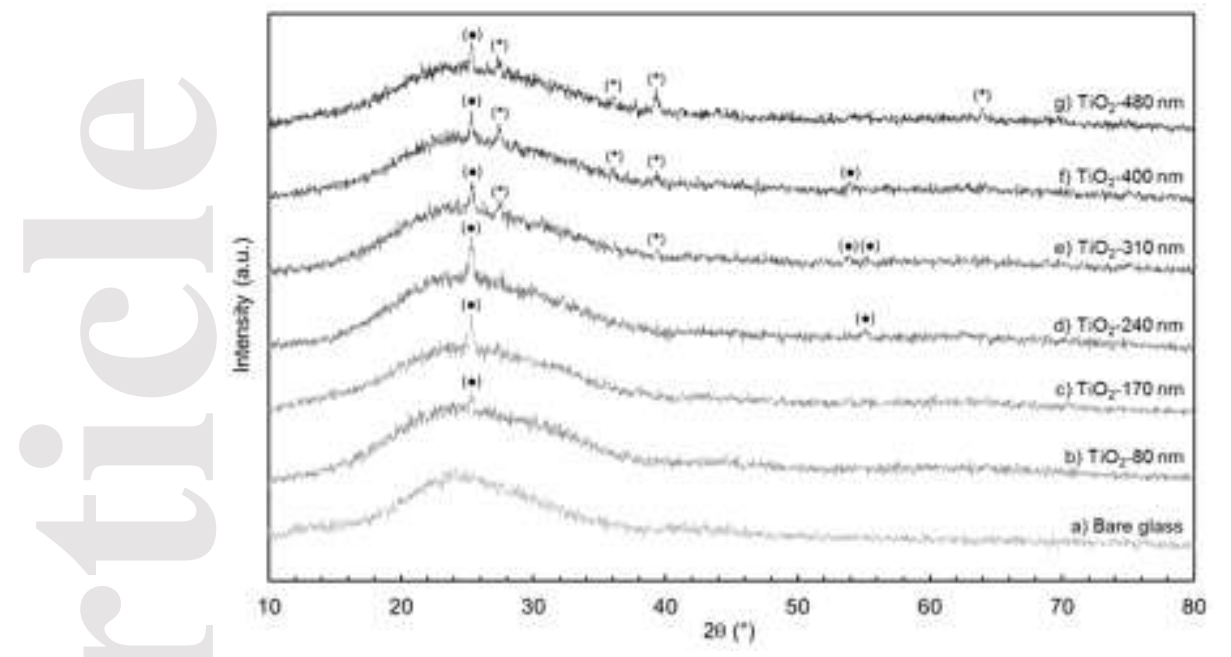



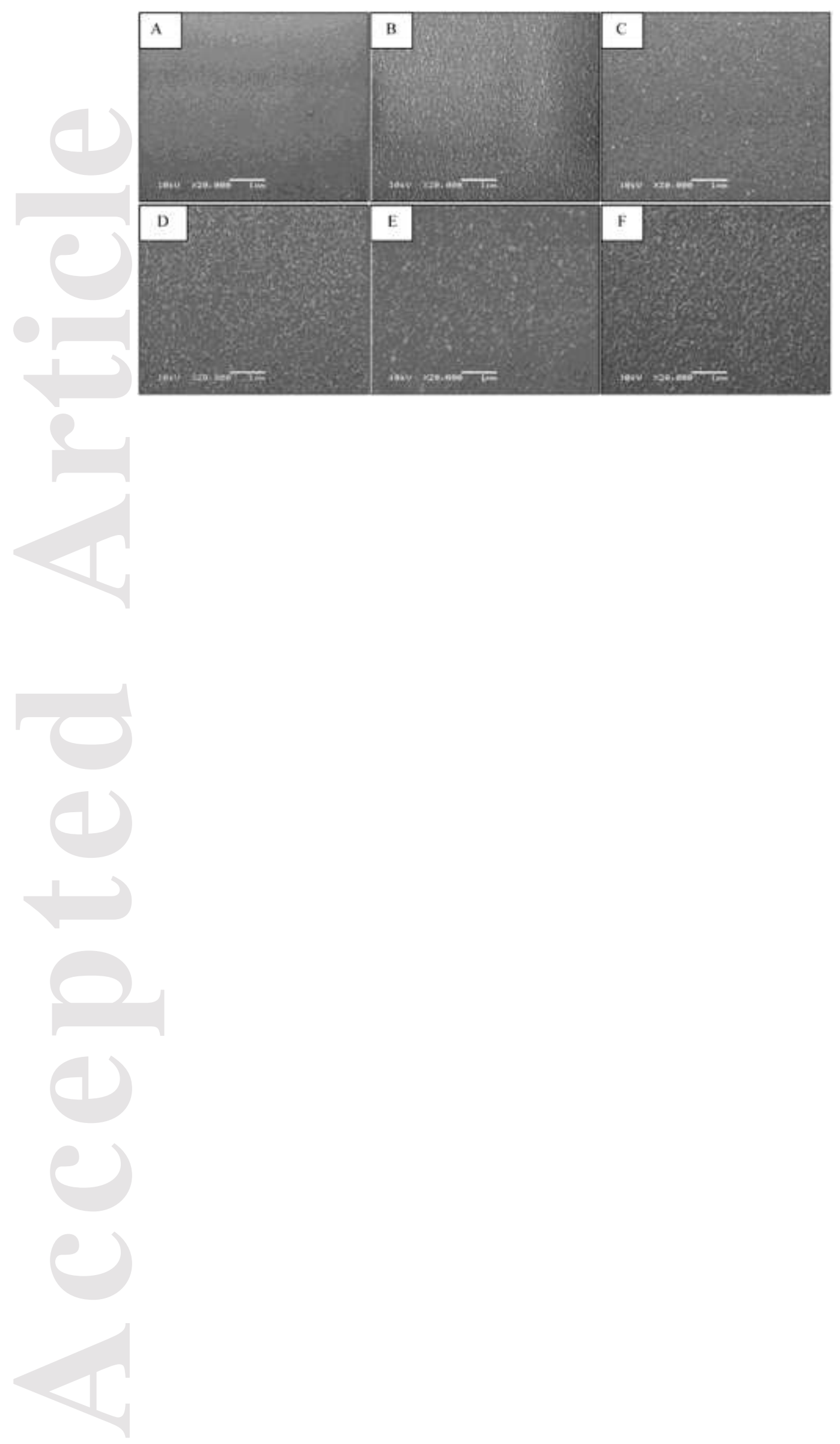


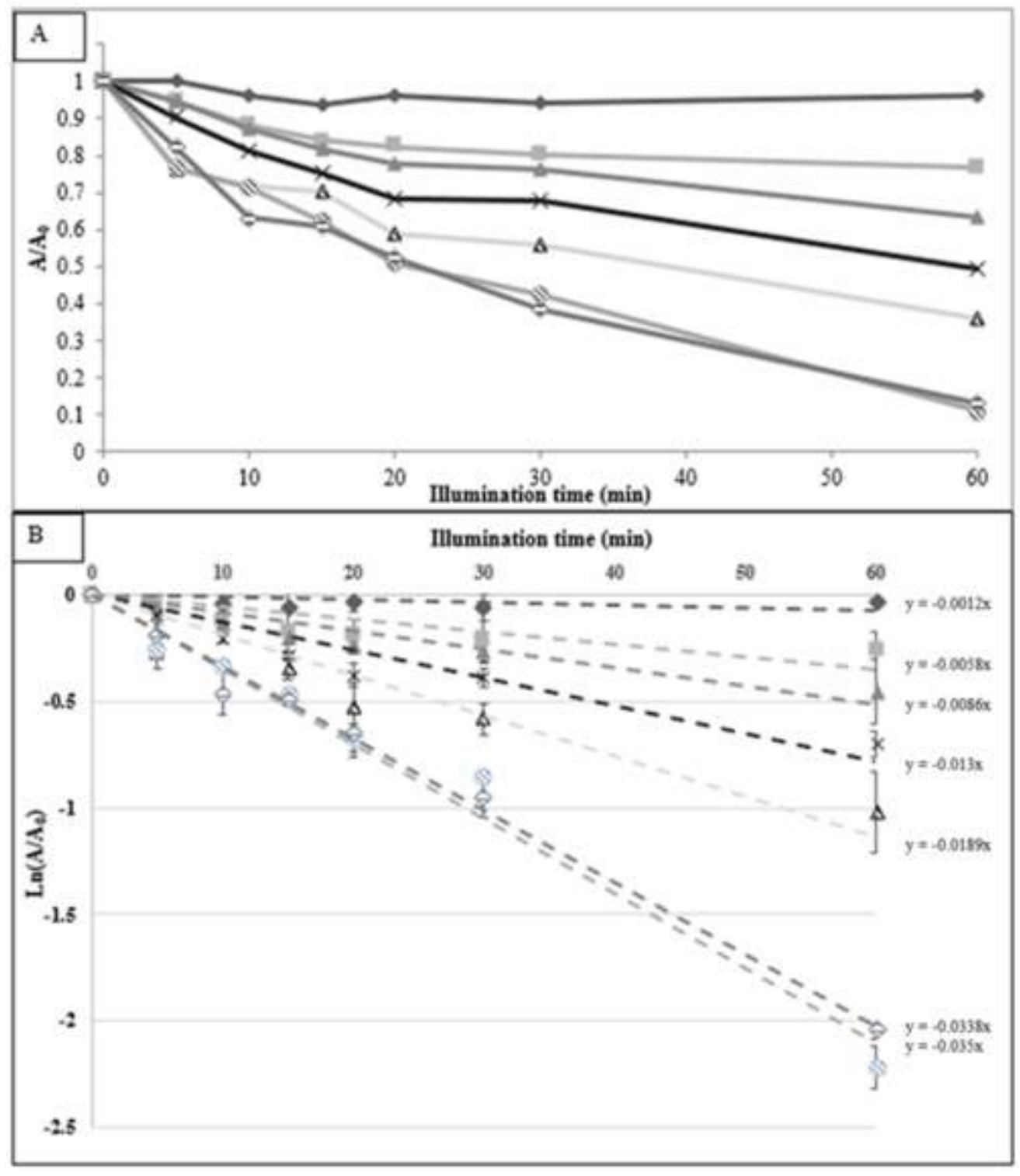



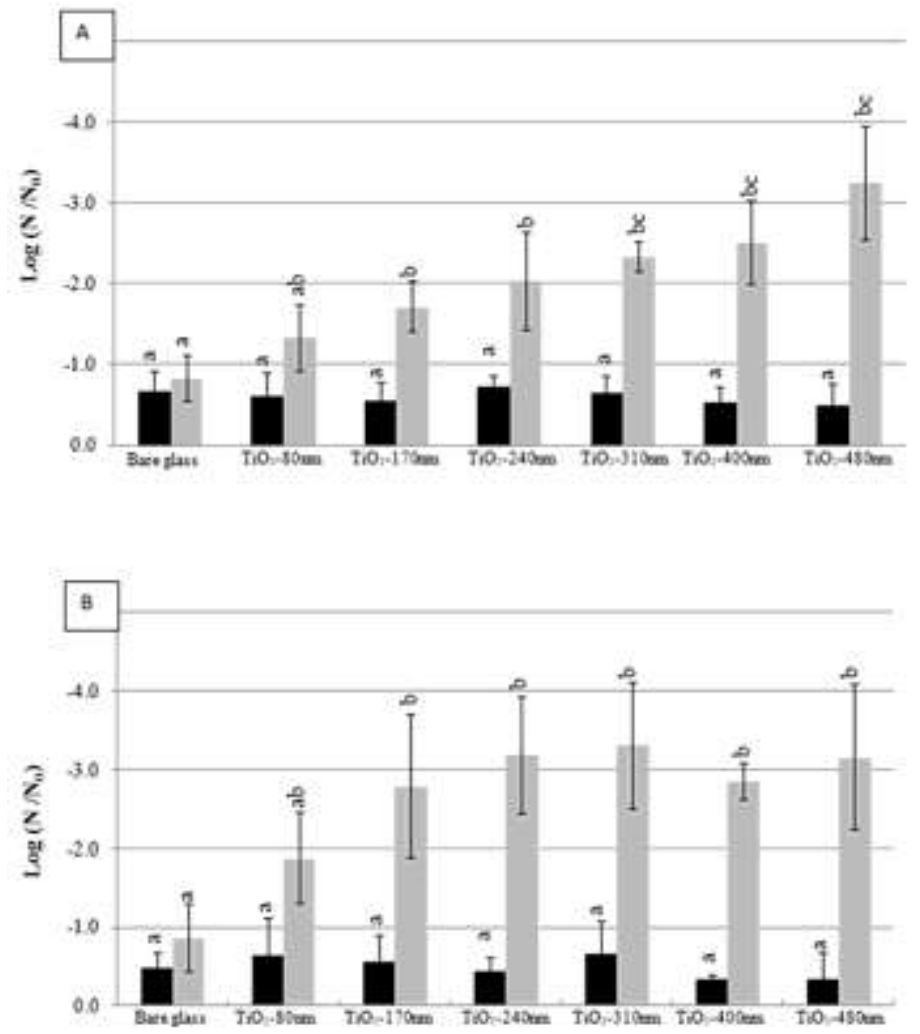


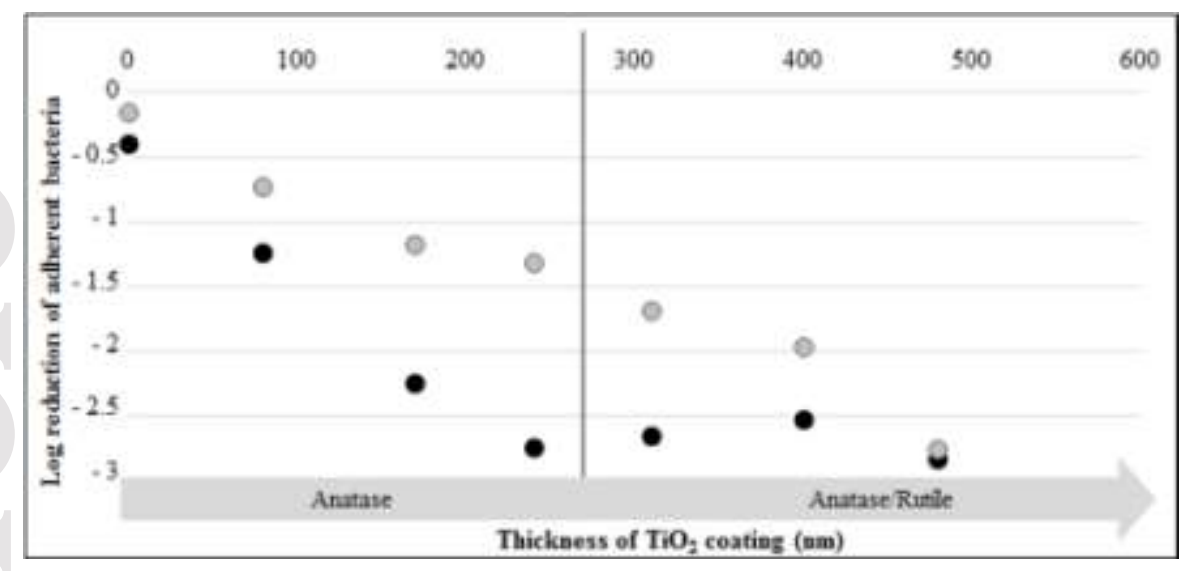




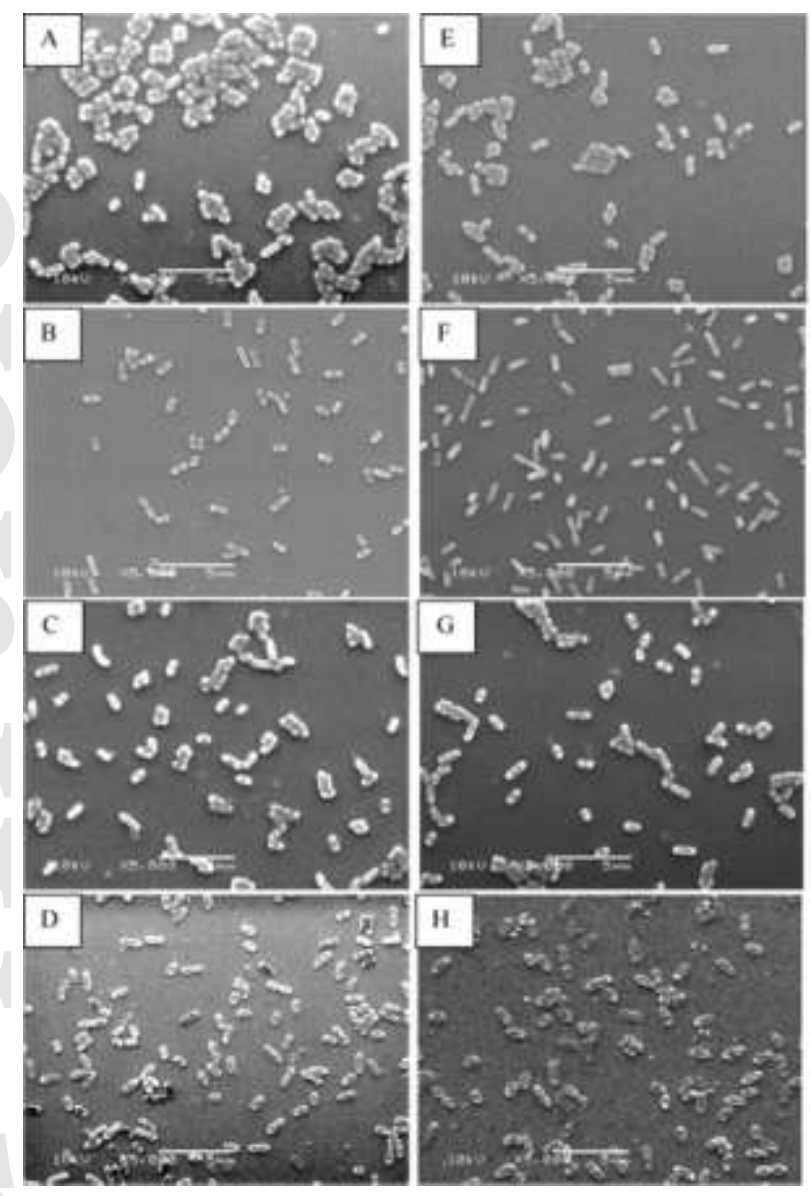




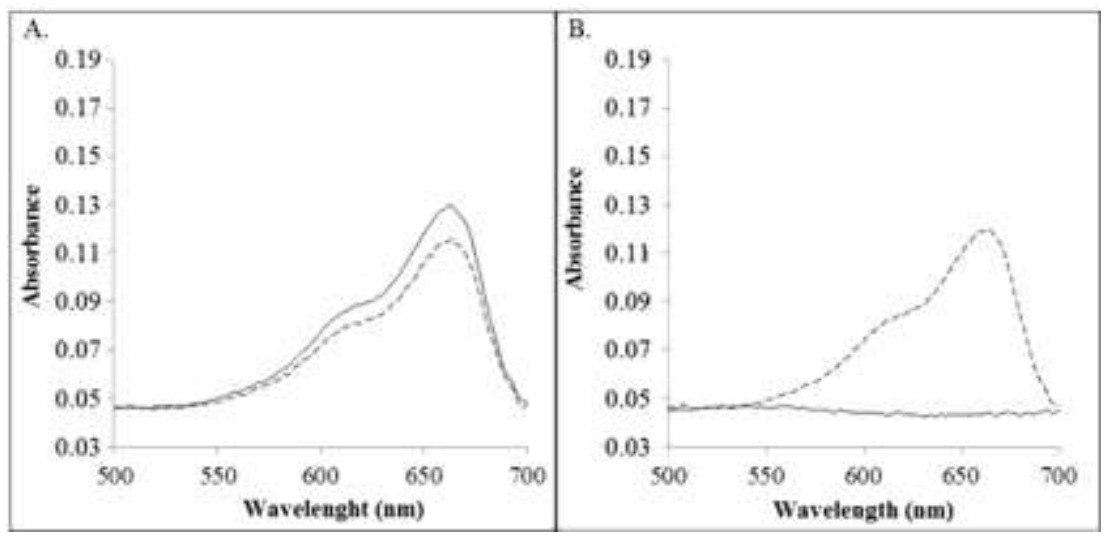

